\title{
ПРОБЛЕМИ ЗМІСТУ ТЕХНІКО-ТАКТИЧНОЇ ПІДГОТОВКИ ВАРІАТИВНОГО МОДУЛЯ«ГАНДБОЛ» НАВЧАЛЬНОЇ ПРОГРАМИ З ФІЗИЧНОЇ КУЛЬТУРИ ДЛЯ ЗАГАЛЬНООСВІТНІХ НАВЧАЛЬНИХ ЗАКЛАДІВ (5-9 КЛАСИ)
}

\author{
Михайло Оліяр ${ }^{1}$ \\ ${ }^{1}$ Тернопільський національний педагогічний університет імені Володимира Гнатюка, \\ Тернопіль, Україна, oliyar1111@ukr.net
}

https://doi.org/10.29038/2220-7481-2018-04-29-35

\begin{abstract}
Анотації
Aктуальність. Реформування освіти в Україні відбувається 3-поміж іншого за допомогою модернізації навчальних програм. В основу чинної навчальної програми з фізичної культури для загальноосвітніх навчальних закладів (5-9 класи) покладено зміст програми від 2009 р., про необхідність удосконалення якої висловлювалися думки у фаховій літературі. Значна активність учасників громадського обговорення, що передувало внесенню змін до цієї навчальної програми у 2017 р., підтвердила наявність недоліків та необхідність її корегування. Проте, як свідчить «Звіт про роботу, виконану робочою групою з оновлення програми «Фізична культура. 5-9 кл.»», ураховано лише 10 пропозицій та й самі укладачі оновленого документа суттєвих змін, окрім деяких термінологічних корекцій, до змісту модулів не внесли. Мета дослідження - визначення проблем змісту технікотактичної підготовки варіативного модуля «Гандбол» навчальної програми з фізичної культури для 5-9-х класів (2017 р.) та пошуку способів їх усунення. Методи дослідження - теоретичний аналіз нормативно-правової бази сфери освіти, теоретичний аналіз й узагальнення даних наукової та методичної літератури. Результати. У статті досліджено зміст техніко-тактичної підготовки варіативного модуля «Гандбол» навчальної програми з фізичної культури для 5-9-х класів. Визначено обсяг запропонованого для вивчення матеріалу, методичну послідовність опануння технічних і тактичних елементів, структурованість навчального матеріалу та його науковість. Запропоновано способи усунення термінологічних та методичних недоліків. Висновки. Дослідження змісту варіативного модуля «Гандбол» навчальної програми з фізичної культури для загальноосвітніх навчальних закладів (5-9 класи) виявило недоліки, пов'язані з неповним обсягом запропонованого до вивчення матеріалу, невідповідність методичної послідовності засвоєння елементів техніки й тактики рекомендаціям спеціальної літератури, хиби використаної термінології.
\end{abstract}

Ключові слова: оновлення навчальної програми, гандбол, техніка, тактика, методика, термінологія.

Михаил Олияр. Проблемы содержания технико-тактической подготовки вариативного модуля «Гандбол» учебной программы по физической культуре для общеобразовательных учебных заведений (5-9 классы). Актуальность. Реформирование образования в Украине происходит, среди прочего, через модернизацию учебных программ. В основе действующей учебной программы по физической культуре для общеобразовательных учебных заведений (5-9 классы) лежит содержание программы от 2009 г., о необходимости совершенствования которой высказывались мнения в профессиональной литературе. Значительная активность участников общественного обсуждения, которое предшествовало внесению изменений данной учебной программы в 2017 г., подтвердила наличие недостатков и необходимость ее корректировки. Однако, как свидетельствует «Отчет о работе, проделанной рабочей группой по обновлению программы «Физическая культура. 5-9 кл.»», учтено только 10 предложений и сами составители обновленного документа существенных изменений, кроме некоторых терминологических коррекций, к содержанию модулей не внесли. Цель исследования определение проблем содержания технико-тактической подготовки вариативного модуля «Гандбол» учебной программы по физической культуре для 5-9-х классов (2017 г.) и поиска путей к их устранению. Memoды исследования - теоретический анализ нормативно-правовой базы сферы образования, теоретический анализ и обобщение данных научной и методической литературы. Результаты. В статье исследовалось содержание технико-тактической подготовки вариативного модуля «Гандбол» учебной программы по физической культуре для 5-9-х классов. Определяется объем предложенного для изучения материала, методическая последовательность изучения технических и тактических элементов, структурированность учебного материала и его научность. Предлагаются пути устранения терминологических и методических недостатков. Выводы. Исследование содержания вариативного модуля «Гандбол» учебной программы по физической культуре для общеобразовательных учебных заведений (5-9 классы) показало недостатки, связанные с неполным объемом предлагаемого к изучению материала, несоответствие методической последовательности усвоения элементов техники и тактики рекомендациям специальной литературы, недостатки используемой терминологии.

Ключевые слова: обновление учебной программы, гандбол, техника, тактика, методика, терминология. 
Mykhailo Oliiar. Problems of the Content of the Technical and Tactical Preparation of the Variational Module «Handball» of the Curriculum on Physical Education for General Education Institutions (Grades 5-9). Relevance. The reform of education in Ukraine is carried out, among other things, through the modernization of curricula. The basis of the current curriculum in physical education for general educational institutions (grades 5-9) is the content of the program 2009 which about the needs to be improved according to professionals. The considerable activity of the public commentators precededing the introduction of changes to this curriculum in 2017, confirmed the presence of deficiencies and the need for its updating. However, as evidenced by the «Report on the work done by the working group on updating the program «Physical Education. Grades 5-9» only 10 proposals were taken into consideration account and the authors of the updated document themselves did not make significant changes to the content of the modules except for some terminological corrections. The purpose of the research is to identify the content of the technical and tactical training of the optional «Handball» module of the physical education curriculum for grades 5-9 (2017) and to find ways to eliminate them. Research methods - theoretical analysis of the regulatory framework of education, theoretical analysis and synthesis of scientific and methodological literature data. Results. The article examines the content of the technical-tactical training of the optional Handball module of the physical education curriculum for grades 5-9. The volume of the material proposed for the study, the methodical sequence of studying the technical and tactical elements, the structure frame of the educational material and its scientific nature were determined. The ways of eliminating terminological and methodical deficiencies are proposed. Conclusions. The study of the content of the optional «Handball» module of the physical culture curriculum for general education schools (grades 5-9) showed deficiencies related to an incomplete amount of material offered for study, discrepancy between the methodical sequence of mastering the elements of technology and tactics and recommendations of special literature and the terminology used.

Key words: updated curriculum, handball, technique, tactic, methods, terminology.

Вступ. Освіта в Україні стала на шлях реформ. Це - вимога часу. Без глибоких модернізаційних змін національній системі освіти важко бути не те що конкурентною в європейському економічному та культурному просторі, а й загалом повноцінно функціонувати. Основою реформ освітньої галузі повинна стати «Концепція нової української школи», що передбачає ціннісні, структурні, системні зрушення [1]. Національна рада реформ, що є платформою для генерації суті та пріоритетних векторів змін, одним із першочергових завдань називає комплексне оновлення навчальних програм, передумовою якого $є$ детальний аналіз відповідних чинних документів i пошук способів їх удосконалення [2]. Активна діяльність Міністерства освіти та науки щодо реформування освіти загалом та фізичної культури зокрема виражена в нормативно-правових змінах. Так, у вересні 2017 р. набрав чинності Закон України «Про освіту» [3]. Також результатом широкого громадського, наукового й експертного обговорення є оновлена навчальна програма $з$ фізичної культури для початкової школи та затверджена Наказом Міністерства освіти і науки України (від 07.06.2017), «Навчальна програма 3 фізичної культури для загальноосвітніх навчальних закладів. 5-9 класи» [4]. Стосовно останнього документа, то активність учасників громадського обговорення змін до цієї навчальної програми (465 коментарів) [5] підтвердила наявність недоліків і необхідність їі корегування. Проте, як свідчить «Звіт про роботу, виконану робочою групою з оновлення програми «Фізична культура. 5-9 кл.», ураховано лише 10 пропозицій та й самі укладачі оновленого документа суттєвих змін, окрім деяких термінологічних корекцій, до змісту модулів не внесли. В основі залишилися модулі навчальної програми $з$ фізичної культури для 5-9-х класів, виданої у 2009 р. та перевиданої у 2012 р.

Аналіз останніх досліджень та публікацій. Навчальні програми з фізичної культури для загальноосвітніх навчальних закладів для 5-9-х класів від 2009 та 2012 рр. були предметом дослідження Б. М. Шияна, І. О. Омеляненко, Н. С. Сорокаліт.

Так, результати дисертаційної роботи Н. С. Сороколіт [6] доводять ефективність модульної програми для підвищення рівня фізичної підготовленості школярів, а також позитивне ставлення до неї учнів та вчителів. Автором здебільшого акцентовано на варіантах оптимального поєднання модулів упродовж навчального року й на умовах їх практичного застосування. При цьому зміст варіативних складників навчальної програми не оцінювався.

Більш детально навчальний матеріал програми досліджено в роботі Б. М. Шияна та І. О. Омеляненко [7]. Автори звертають увагу як на позитивні сторони документа, що сприяють демократизації й гуманізації процесу фізичного виховання в школі, так і вказують на негативні моменти, що стосуються методичного та змістового наповнення модулів і фахової термінології. Науковці рекомендують публічно обговорювати проекти нових чи зміни до чинних державних документів планування з фізичного виховання задля уникнення вад у їх змісті.

Ураховуючи курс держави на вдосконалення навчально-виховного процесу у школі та думки фахівців у галузі фізичного виховання щодо змісту навчальної програми з фізичної культури для 59-х класів за 2009 та 2012 рр., зміст модулів якої практично повністю покладено основу чинної навчальної програми, визначено мету дослідження. 
Мета статті - визначити проблеми змісту техніко-тактичної підготовки варіативного модуля «Гандбол» навчальної програми з фізичної культури для 5-9-х класів (2017р.) і способи їх усунення.

Завдання дослідження:

1) визначити перелік та послідовність технічних і тактичних елементів, запропонованих до вивчення в модулі «Гандбол» навчальної програми з фізичної культури для 5-9-х класів;

2) оцінити відповідність змісту техніко-тактичної підготовки варіативного модуля «Гагдбол» методичним вимогам до навчання гандболу.

Матеріал і методи дослідження - теоретичний аналіз нормативно-правової бази сфери освіти, теоретичний аналіз та узагальнення даних наукової й методичної літератури.

Результати дослідження. Аналіз змісту навчального матеріалу техніко-тактичної підготовки варіативного модуля «Гандбол» навчальної програми з фізичної культури для 5-9-х класів засвідчив, що, окрім переліку технічних й тактичних елементів, там подано ще й іншу інформацію. Так, «передачі в парах», «передача та ловіння м'яча в трійках», «кидки в ціль правою й лівою рукою», «передача в русі парами зі зміною місць», «кидки по воротах», «навчальна гра за спрощеними правилами», «ігрова вправа $2 \times 1$ та $2 \times 2 »$, «міні-гандбол» й ін. - це засоби навчання та техніко-тактичного вдосконалення, а не технічними прийомами.Такі вправи, як «передача та ловіння м'яча в трійках із паралельним пересуванням», «рух схресно», підміняють елементи групових тактичних дій у нападі взаємодія при паралельному переміщенні та взаємодія при переміщенні зі схрещенням [Циганок]. Певні терміни, наявні в змісті, стосуються не техніко-тактичної підготовки, а правил гандболу: семиметровий кидок, вільний кидок. А таке поняття, як «штрафний кидок», у гандболі взагалі не використовується.

Для дослідження переліку та послідовності запропонованих для засвоєння техніко-тактичних елементів варіативного модуля «Гандбол» навчальної програми сформовано таблиці, де із-поміж інформації, поданої в змісті навчального матеріалу техніко-тактичної підготовки виокремлено технічні прийоми й елементи тактики та подано їх за роками вивчення (табл.1,2).

Відповідність змісту техніко-тактичної підготовки методичним вимогам до навчання гандболу, наведеним у фаховій літературі [8; 9; 10], визначали за такими критеріями:

- обсяг запропонованого для вивчення матеріалу;

- методична послідовність вивчення технічних і тактичних елементів;

- структурованість навчального матеріалу;

- науковість.

Таблиця 1

Зміст технічної підготовки варіативного модуля «Гандбол» за роками вивчення (стійки та переміщення гравців, ловіння, передачі, кидки, ведення)

\begin{tabular}{|c|c|c|c|c|c|}
\hline \multicolumn{6}{|c|}{ Зміст навчального матеріалу } \\
\hline \multirow{3}{*}{$\begin{array}{c}\text { Рік } \\
\text { вивчення }\end{array}$} & \multicolumn{5}{|c|}{ Техніка гандболу } \\
\hline & $\begin{array}{c}\text { стійки та } \\
\text { переміщення }\end{array}$ & поріння & перелачі & КИпи & редения \\
\hline & $\begin{array}{c}\text { у нападі та } \\
\text { захисті } \\
\end{array}$ & JODITIIn & Переда пो & КИдки & Бедепाम \\
\hline 1 & 2 & 3 & 4 & 5 & 6 \\
\hline 1 & $\begin{array}{l}\text { Стійка гандболіста. } \\
\text { Пересування, } \\
\text { зупинка двома } \\
\text { кроками. }\end{array}$ & $\begin{array}{l}\text { Ловіння } \\
\text { м'яча } \\
\text { обома } \\
\text { руками. }\end{array}$ & $\begin{array}{l}\text { Передача м’яча } \\
\text { однією та двома } \\
\text { руками з місця. }\end{array}$ & $\begin{array}{l}\text { Кидок м'яча зігнутою } \\
\text { рукою зверху. } \\
\text { Кидки в ціль правою та } \\
\text { лівою руками. }\end{array}$ & $\begin{array}{l}\text { Ведення м'яча } \\
\text { кроком правою та } \\
\text { лівою руками, } \\
\text { обведення стійок. }\end{array}$ \\
\hline 2 & $\begin{array}{l}\text { Способи } \\
\text { пересування гравців } \\
\text { по майданчику в } \\
\text { нападі та захисті. } \\
\text { Пересування } \\
\text { гравців без м'яча. }\end{array}$ & $\begin{array}{l}\text { Ловіння } \\
\text { м'яча } \\
\text { двома } \\
\text { руками } \\
\text { знизу, на } \\
\text { рівні } \\
\text { грудей, } \\
\text { зверху. }\end{array}$ & $\begin{array}{l}\text { Передача з-за } \\
\text { голови та від плеча } \\
\text { на місці та в русі. } \\
\text { Передача в русі } \\
\text { парами зі зміною } \\
\text { місць. } \\
\text { Різноманітні } \\
\text { передачі з різною } \\
\text { траєкторією руху } \\
\text { м’яча. }\end{array}$ & $\begin{array}{l}\text { Кидки правою й лівою } \\
\text { рукою зверху із замахом } 3 \\
\text { місця та в русі. } \\
\text { Кидки по воротах. } \\
\text { Штрафний і вільний кидки } \\
\text { з опорного положення. }\end{array}$ & 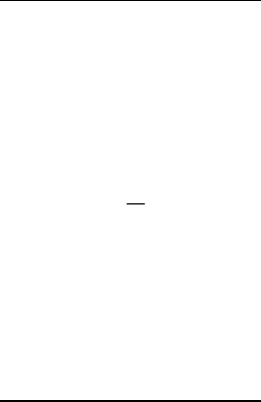 \\
\hline
\end{tabular}


Закінчення таблиці 1

\begin{tabular}{|c|c|c|c|c|c|}
\hline 1 & 2 & 3 & 4 & 5 & 6 \\
\hline 3 & $\begin{array}{l}\text { Пересування } \\
\text { гравців. Способи } \\
\text { пересування в } \\
\text { нападі та захисті. }\end{array}$ & $\begin{array}{l}\text { Ловіння } \\
\text { м’яча, що } \\
\text { котиться. }\end{array}$ & $\begin{array}{l}\text { Передача й } \\
\text { ловіння м'яча при } \\
\text { зустрічному русі. }\end{array}$ & $\begin{array}{l}\text { Кидок «хльостом» } 3 \\
\text { опорного положення. } \\
\text { 7-метровий штрафний } \\
\text { кидок. }\end{array}$ & $\begin{array}{l}\text { Ведення м'яча } 3 \\
\text { різною } \\
\text { амплітудою } \\
\text { відскоку. }\end{array}$ \\
\hline 4 & - & - & $\begin{array}{l}\text { Кистьова, скрита } \\
\text { передача м’яча. }\end{array}$ & $\begin{array}{l}\text { Кидки м’яча в опорному } \\
\text { положенні з відхиленням } \\
\text { тулуба, із 1-2-3 кроків, } \\
\text { кидки в падінні. } \\
\text { Вільний кидок. Кидок із } \\
\text { відскоком від підлоги. }\end{array}$ & - \\
\hline 5 & - & - & - & $\begin{array}{l}\text { Кидки з опорного } \\
\text { положення та в русі під } \\
\text { час активного опору } \\
\text { суперника. тактика } \\
\text { Кидки з підкручуванням } \\
\text { м’яча. }\end{array}$ & - \\
\hline
\end{tabular}

Табличя 2

Зміст технічної та тактичної підготовки варіати вного модуля «Гандбол» за роками вивчення (обманні рухи, техніка заволодіння м'ячем і протидії, техніка воротаря, тактика нападу та захисту)

\begin{tabular}{|c|c|c|c|c|c|}
\hline \multicolumn{6}{|c|}{ Зміст навчального матеріалу } \\
\hline \multirow{3}{*}{$\begin{array}{c}\text { рік } \\
\text { вивчення }\end{array}$} & \multicolumn{3}{|c|}{ техніка гандболу } & \multicolumn{2}{|c|}{ тактика гандболу } \\
\hline & \multirow{2}{*}{ обманні рухи } & \multirow{2}{*}{$\begin{array}{c}\text { Техніка } \\
\text { заволодіння } \\
\text { м'ячем та } \\
\text { протидії }\end{array}$} & \multirow{2}{*}{$\begin{array}{l}\text { техніка } \\
\text { воротаря }\end{array}$} & тактика нападу & тактика захисту \\
\hline & & & & $\begin{array}{c}\text { польового гравця, } \\
\text { воротаря }\end{array}$ & $\begin{array}{c}\text { польового } \\
\text { гравця, воротаря }\end{array}$ \\
\hline 1 & 2 & 3 & 4 & 5 & 6 \\
\hline 1 & - & - & - & \multicolumn{2}{|c|}{$\begin{array}{l}\text { Розміщення гравців на ігровому } \\
\text { майданчику }\end{array}$} \\
\hline 2 & - & - & $\begin{array}{l}\text { Гра воротаря. } \\
\text { Стійка та } \\
\text { переміщення у } \\
\text { воротах. } \\
\text { Відбивання } \\
\text { м’ячів однією й } \\
\text { двома руками. }\end{array}$ & - & - \\
\hline 3 & $\begin{array}{l}\text { Фінт на } \\
\text { передачу, фінт } \\
\text { переміщенням в } \\
\text { одну сторону, а } \\
\text { вихід і кидок в } \\
\text { іншу. Обманні } \\
\text { рухи з } \\
\text { відхиленням } \\
\text { управо, уліво. }\end{array}$ & - & $\begin{array}{l}\text { Техніка } \\
\text { відбивання м'ячів. } \\
\text { Випади воротаря } \\
\text { на кидки в нижні } \\
\text { куги воріт. }\end{array}$ & $\begin{array}{l}\text { Дії, що відволікають } \\
\text { увагу суперника. } \\
\text { Заслони. Внутрішній } \\
\text { і зовнішній для } \\
\text { виходу партнера на } \\
\text { атаку. } \\
\text { Командні дії. } \\
\text { Амплуа «лінійного». }\end{array}$ & $\begin{array}{l}\text { Позиція воротаря } \\
\text { під час відбивання } \\
\text { кидків із 7-9 м. } \\
\text { Вихід із-під } \\
\text { заслонів. }\end{array}$ \\
\hline 4 & 2 & $\begin{array}{l}\text { Блокування } \\
\text { гравця тулубом. } \\
\text { Перехват м'яча } \\
\text { під час передачі, } \\
\text { блокування } \\
\text { кидків. }\end{array}$ & - & Схресний рух & $\begin{array}{l}\text { Змішанийзахист } \\
(5+1),(4+2) . \\
\text { Взаємодія воротаря } \\
\text { із захисником. } \\
\text { Командні дії в } \\
\text { нападі та захисті }\end{array}$ \\
\hline
\end{tabular}


Закінчення таблииі 2

\begin{tabular}{|c|c|c|c|c|c|}
\hline 1 & 2 & 3 & 4 & 5 & 6 \\
\hline 5 & $\begin{array}{l}\text { Вихід на м’яч } \\
\text { із виконанням } \\
\text { дій, що } \\
\text { відволікають } \\
\text { увагу } \\
\text { суперника } \\
\text { (фінти) }\end{array}$ & - & - & $\begin{array}{l}\text { Рух вісімкою. } \\
\text { Тактичні дії в } \\
\text { захисті та нападі. } \\
\text { Напад } \\
\text { контратакою, } \\
\text { позиційний напад. } \\
\text { Виконання кидків } \\
\text { м’яча із закритих } \\
\text { позицій. Взаємодія } \\
\text { гравців у нападі. } \\
\text { Вихід на вільне } \\
\text { місце. } \\
\text { Взаємодія гравців } \\
\text { під час нападу } \\
\text { «швидкий прорив» } \\
\text { 2х4; 3х3. }\end{array}$ & $\begin{array}{l}\text { Персональний та } \\
\text { позиційний } \\
\text { захист. } \\
\text { Підстраховка, } \\
\text { підсилення в } \\
\text { захисті. } \\
\text { Тактика гри } \\
\text { воротаря. } \\
\text { Визначення } \\
\text { напрямку } \\
\text { можливої атаки. } \\
\text { Взаємодія із } \\
\text { захисниками. } \\
\text { Корегування } \\
\text { діями захисників. } \\
\text { Командні дії в } \\
\text { захисті 6х0; 5х1 }\end{array}$ \\
\hline
\end{tabular}

Аналіз змісту техніко-тактичної підготовки варіативного модуля «Гандбол» навчальної програми (табл. 1, 2) засвідчив, що перелік технічних прийомів й основних елементів тактики, наведених у навчальній програмі, є неповним. Так, серед базових елементів техніки нападу відсутні тримання м'яча, ловіння м'яча однією (із захопленням та без), передачі поштовхом від грудей, найпоширеніший спосіб передач - передачі хльостом, способи розбігу при кидках із розбігу з опорного положення, найефективніший вид кидків у гандболі - кидок у стрибку, одноударне ведення. Із-поміж прийомів захисту польового гравця до вивчення не запропоновано вибивання м'яча під час ведення, а серед переліку прийомів гри воротаря немає затримання м'яча. Проте є такі складні технічні елементи, як кидки 3 підкручуванням, кидки з відхиленням і травмонебезпечні кидки в падінні. Перелік основних тактичних дій також неповний. Зокрема, відсутні такі нескладні дії, як прослизання та переключення, проте $є$ пов'язані з ними й більш складні - внутрішній та зовнішній заслони; немає групових дій із паралельним переміщенням, але є складніші - зі схресним переміщенням. Із чотирьох ігрових амплуа польових гравців пропонується розглядати лише одне - «лінійне».

Методична послідовність вивчення технічних і тактичних елементів, подана в навчальній програмі, як у межах року, так і впродовж усього періоду вивчення модуля, також потребує корегування. Зокрема, окремі групи технічних прийомів у змісті модуля навчальної програми подаються в послідовності, рекомендованій у фаховій літературі $[8 ; 9 ; 10]$, (наприклад, упродовж другого року вивчення рекомендується вивчати техніку переміщень ловіння, передачі двома, передачі однією, кидки), проте послідовність запропонованих до вивчення деяких елементів $є$ методично необгрунтованою. Так, на першому році вивчення пропонується засвоїти «ведення м'яча кроком правою та лівою руками, обведення стійок, ловіння м'яча обома руками». У цьому переліку суперечливе те, що «ловіння» подається й може трактуватися педагогом, як рекомендація вивчати цей прийом уже після ведення, а опанування техніки володіння м'ячем починати з ведення, що не відповідає логіці засвоєння техніки гандболу. Також на першому році в програмі пропонується вивчати передачі однією та двома руками. За відсутністю уточнень можна зробити висновок, що це передачі поштовхом (це випливає з логіки процесу засвоєння передач i з того, що на другому році пропонується вивчати лише передачі поштовхом). Проте в змісті навчального матеріалу вже наявні кидки хльостом, що методично не виправдано, адже до виконання кидків хльостом учнів має підвести виконання передач тим самим способом. Техніку передач хльостом упродовж вивчення гандболу в навчальній програмі засвоювати взагалі не пропонується. Порушення методичної послідовності виявлено й під час планування навчання тактичних дій. Так, на 4-му році вивчення модуля «Гандбол» пропонується навчати змішаного захисту, а на 5-му - особистого та зонного. У цьому випадку не враховано те, що змішаний захист $€$ поєднанням особистого й зонного видів захисту та вивчається після їх засвоєння. 
Деякі технічні прийоми гандболу дублюються впродовж декількох років вивчення. Аналіз навчального матеріалу свідчить, що різними назвами позначається один і той самий прийом. Так, «пересування», «способи пересування гравців по майданчику в нападі й захисті», «способи пересування в нападі та захисті», у зазначеному порядку є змістом техніко-тактичної підготовки впродовж трьох років вивчення модуля. Також запропоноване для вивчення на другому році «ловіння м'яча двома руками знизу, на рівні грудей, зверху» дублює матеріал першого року - «ловіння м'яча обома руками». Повторення матеріалу відбувається й під час вивчення кидків. Так, упродовж перших трьох років засвоєння модуля пропонується виконувати кидок зігнутою рукою зверху з опорного положення 3 місця, лише його назва подається по-різному: «кидок м'яча зігнутою рукою зверху», «кидки правою й лівою руками зверху із замахом з місця та в русі», «кидок «хльостом» 3 опорного положення». При цьому не уточнюються ні різновиди, ні умови виконання кидка цим способом. Якщо, на думку авторів модуля «Гандбол» навчальної програми, таке дублювання $є$ умовою вдосконалення зазначених прийомів упродовж багаторічного періоду засвоєння гандболу, то варто було б у кожній із річних частин модуля застосовувати ідентичну термінологію для їх означення, а також дублювати не лише зазначені, а й інші технічні й тактичні елементи.

Дезорганізувати процес вивчення гандболу може й те, що назви технічних прийомів, поданих у змісті техніко-тактичної підготовки, не $\epsilon$ конкретними та повними. Так, на першому році пропонується для навчання «передача м'яча однією й двома руками з місця», проте не вказується спосіб ії виконання (поштовхом, хльостом чи кистьова; зверху або знизу тощо). Також стосовно «ловіння м'яча обома руками» не вказується, чи м'яч котиться, летить на середній висоті, летить високо або після відскоку. Із поданих у навчальній програмі назв зазначених технічних прийомів випливає, що навчати передавати чи ловити м'яч усіма способами потрібно вже на першому році вивчення гандболу. Але ж у змісті модуля наступних років способи й умови виконання цих прийомів уже конкретизуються та пропонуються для вивчення в певній послідовності. Аналогічна ситуація із кидком зігнутою рукою зверху. Так, на першому році вивчення модуля учням пропонується оволодіти «кидком м'яча зігнутою рукою зверху», але цей кидок може виконуватися 3 місця, із розбігу, з опорного та безопорного положень тощо. На наступному році той самий технічний прийом, хоча не зовсім коректно (кидок зверху передбачає попередній замах; виконується не в русі, а з розбігу), подається вже дещо уточненим - «кидки правою й лівою руками зверху із замахом із місця та в русі».

Не сприяє якісній організації процесу засвоєння модуля «Гандбол» недосконала, а в деяких випадках і помилкова термінологія, використана під час формування його змісту. Так, трапляються зайві уточнення, що суперечать спортивній термінології: кидок із відскоком від підлоги, кидки правою й лівою руками зверху із замахом, кидки по воротах, штрафний і вільний кидки з опорного положення. До того ж використовуються різні назви одного й того самого прийому: ловіння, пересування та переміщення. Подекуди вказуються елементи техніки, яких немає в класифікації техніки гандболу: зупинка двома кроками, передача 3-за голови. Також трапляються русизми («перехват»-перехоплення; «скрита» передача - прихована передача) та поняття, що не відповідають гандбольній термінології («опір суперника» - протидія; «амплітуда відскоку» - висота відскоку).

Висновки. В основу навчального матеріалу варіативного модуля «Гандбол» навчальної програми 3 фізичної культури для загальноосвітніх навчальних закладів (5-9 класи) від 2017 р. покладено зміст навчальної програми від 2009 р., що, на думку фахівців, потребує грунтовного аналізу, усунення недоліків та модернізації. Аналіз змісту техніко-тактичної підготовки, запропонованого в цьому модулі, показав відсутність у документі повного обсягу основних елементів техніки та тактики гри. Виявлено невідповідність запропонованої послідовності вивчення елементів гандболу як у межах окремого року, так і впродовж усього періоду засвоєння модуля методичним вимогам до навчання техніки та тактики цієї гри. Перелік елементів техніко-тактичної підготовки в змісті навчальної програми подано в хаотичному порядку із вкрапленням засобів навчання й положень правил. Наявні в документі недоліки термінології знижують його статус і дезорганізують процес навчання гандболу.

Перспективи подальших досліджень. Проаналізувати інші варіативні модулі програми 3 фізичної культури для загальноосвітніх навчальних закладів (5-9 класи) від 2017 р. та запропонувати способи їх удосконалення.

\section{Джерела та література}

1. Концепція нової української школи. URL: https://osvita.ua/doc/files/news/520/52062/new-school.pdf

2. Національна рада реформ. URL: http://reforms.in.ua/

3. Закон України «Про освіту». URL: http://zakon3.rada.gov.ua/laws/show/2145-19 
4. Міністерство освіти і науки України. Освітні програми. URL: https://mon.gov.ua/ua/osvita/zagalnaserednya-osvita/navchalni-programi

5. Ключові зміни в оновлених навчальних програмах 5-9 класів за результатами обговорення на платформі EdEra та на предметних робочих групах. URL: https://mon.gov.ua/storage/app/media/zagalna\% 20serednya/ programy-5-9-klas/klyuchovi-zmini-v-onovlenix-navchalnix-programax-5-9-klasiv.pdf

6. Сороколіт Н. С. Удосконалення фізичного виховання учнів 5-9 класів із застосуванням варіативних модулів навчальної програми: дис. ... канд. наук з фіз. виховання та спорту: 24.00.02/Львів. держ. ун-т фіз. культури. Львів, 2015. 190 с.

7. Шиян Б., Омельяненко І. Нова програма фізичного виховання школярів: успіхи і невдачі. Фізичне виховання в школі. 2010. № 2. С. 5-7.

8. Драчук А. І. Теорія і методика викладання гандболу: навч. посіб. 2-ге вид., доповн. і переробл. Вінниця, $2011.154 \mathrm{c}$.

9. Спортивные игры. Техника, тактика, методика обучения/под ред. Ю. Д. Железняка, Ю. М. Портнова. Москва: Академия, 2007. - 518 с.

10. Шестаков И. Г., Калашян Р. А. Методика обучения технике передачи мяча. Ярославский педагогический вестник. 2012. № 4. Т. ІІ (Психолого-педагогические науки). С. 135-141.

\section{References}

1. Kontseptsiia novoi ukrainskoi shkoly [The concept of a new ukrainian school]. URL: https://osvita.ua/doc/ files/news/520/52062/new-school.pdf

2. Nacional'na rada reform [The National Council of Reforms]. URL: http://reforms.in.ua/

3. Zakon Ukrayiny «Pro osvitu» [The Law of Ukraine On Education]. URL: http://zakon3.rada.gov.ua/laws/ show/2145-19

4. Ministerstvo osvity i nauky Ukrajiny. Osvitni programy [Ministry of Education and Science of Ukraine. Educational programs]. URL: https://mon.gov.ua/ua/osvita/zagalna-serednya-osvita/navchalni-programi.

5. Kliuchovi zminy v onovlenykh navchalnykh prohramakh 5-9 klasiv za rezultatamy obhovorennia na platformi EdEra ta na predmetnykh robochykh hrupakh [The key changes in the reviewer programs of 5-9 classes for the discussed results within the EdEra platform and the objective working groups]. URL: https://mon.gov.ua/ storage/app/media/zagalna\%20serednya/programy-5-9-klas/klyuchovi-zmini-v-onovlenix-navchalnixprogramax-5-9-klasiv.pdf

6. Sorokolit, N. (2015). Udoskonalennia fizychnoho vykhovannia uchniv 5-9 klasiv iz zastosuvanniam variatyvnykh moduliv navchalnoi prohramy. - Dysertatsiia kand. nauk z fiz. vykhovannia ta sportu [Improvement of physical education of the 5-9 forms' pupils with application of variational modules of the curriculum. Extended abstract of candidate's thesis, Lviv State Un-ty of Phys. Culture.

7. Shyian, B., Omelianenko, I. (2010). Nova prohrama fizychnoho vykhovannia shkoliariv: uspikhy i nevdachi. Fizychne vykhovannia $\mathrm{v}$ shkoli [New program of physical education for schoolchildren: successes and failures]. Fizychne vykhovannja v shkoli, No. 2, 5-7.

8. Drachuk, A. (2011). Teoriia i metodyka vykladannia handbolu: Navchalnyi posibnyk [Theory and methods of handball teaching]: Navchalnyj posibnyk. 2-e vyd., dopovn. i pererobl. - Vinnytsia.

9. Zhelezniak, Ju., Portnova Ju. (Ed.). Sportyvnyje ihry (2007). [The sport games]. Tekhnyka, taktyka, metodyka obuchenia. M., Akademija, 518.

10. Shestakov, I. G. Kalashian, R. A. (2012). Metodyka obucheniya tekhnyke peredachy m ‘acha [Methodology of the ball transfer teaching technology]. - Yaroslavskyi pedahohycheskyi vestnyk. Psykholoho-pedahohycheskye nauky, No. 4, (Vol. 2), 135-141. 